\title{
Szemle
}

\author{
FODOR LÁSZLÓ*
}

\section{A multifunkcionális és fenntartható mezőgazdaság európai modellje}

Az alábbi gondolatokat két, agrárjogi, illetve agrár-környezetjogi témakörben megjelent, német nyelvű monográfia olvasása közben fogalmaztam meg. Az egyik Peter Käb könyve, amelyik a multifunkcionális mezőgazdaság agrárjogi problémáival foglalkozik, ${ }^{1}$ míg a másik szerző, Falk-Rembert von Eickstedt azt a szabályozási folyamatot követi nyomon, amelynek során a gazdálkodó (a farmer) a vidék gondnokává válik. ${ }^{2} \mathrm{~A}$ kötetek ugyanazon neves kiadónál, a Nomosnál, mégpedig a kiadó agrár-, környezet- és fogyasztóvédelmi sorozatának darabjaiként jelentek meg. ${ }^{3}$ Mindkét szerző az Európai Unió Közös Agrárpolitikáját (KAP), illetve az ahhoz kapcsolódó, német tagállami megoldásokat vizsgálja; egymástól látszólag eltérő, de valójában egymáshoz nagyon is közel áló szempontból. Tárgyköreik, módszereik és eredményeik közül azokat emelem ki, amelyek a mai magyar agrár- és környezetjog szempontjából a legérdekesebbnek túnnek.

\section{Nézőpontok, időszerűség}

Miként az agrárjoggal foglalkozók jól tudják, a multifunkcionalitás és a fenntarthatóság két különböző, de egymással mégis összekapcsolódó, sőt bizonyos értelemben átfedésben is lévő jelentéssel bíró kifejezés és követelmény. A KAP szempontjából mindkettő a 90-es évek második felében vált meghatározóvá, és a hagyományos értelemben vett agrárpolitika tárgykörének kiszélesítését jelenti. A multifunkcionalitás az Agenda 2000 c. bizottsági dokumentum (1997) szerint az „európai mezőgazdasá-

* Dr. Fodor László egyetemi tanár, Debreceni Egyetem Állam- és Jogtudományi Kar Agrárjogi, Környezetjogi és Munkajogi Tanszék, fodor.laszlo@law.unideb.hu.

1 КӒв, Peter: Agrarrechtliche probleme einer multifunktionalen Landwirtschaft. Baden-Baden, Nomos, 2010, 443.

2 EICKSTEDT, von, Falk-Rembert: Vom Landwirt zum Landschaftspfleger: Umweltrechtliche Verhaltenssteuerung im Rahmen der Gemeinsamen Agrarpolitik am Beispiel des Akcerbaus. Baden-Baden, Nomos, 2010, 281.

3 A Nomos Kiadó sorozatának címe: Schriften zum Agrar-, Umwelt- und Verbraucherschutzrecht; az 58. és 61. kötetekről van szó. Mindkettő elérhető a Debreceni Egyetemi és Nemzeti Könyvtár gyüjteményében. 
gi modell" sajátossága. Ebben az agrárium gazdasági-társadalmi szerepe nem korlátozódik a mezőgazdasági termékek (élelmiszer, takarmány, nyersanyag s újabban energiahordozó) elöállítására, hanem amellett számos egyéb funkciót is betölt. Munkát ad, hagyományokat őriz, gondozza a vidéki (kultúr-) tájat, az élőlényeknek élöhelyet biztosít, kikapcsolódást nyújt a városi polgároknak stb. A mezőgazdaság támogatása és a vidék népességmegtartó képességének, felzárkóztatásának az elösegítése, valamint a környezetvédelem ily módon összekapcsolódik egymással. A sokszínűség nemcsak a vidéken jellemző tevékenységekre nézve, hanem a mezőgazdasági tevékenységek körén belül is fontos követelmény, hiszen a diverzifikálás a gazdának több lábon állást, a piacon kevesebb felesleget, a társadalomban nagyobb elfogadottságot, környezeti szempontból pedig (pl. a klímaváltozásra vagy a biológiai sokféleségre tekintettel) kevesebb terhelést és a változásokhoz való nagyobb fokú alkalmazkodóképességet eredményez.

A nagyobb fokú, rugalmas alkalmazkodóképesség (manapság egyre divatosabbá váló, $s$ a fenntarthatóság fogalmához képest továbbfejlesztett, továbbgondolt kifejezéssel élve: reziliencia) a környezeti (s persze az iménti példákból is jól láthatóan, amellett a gazdasági és a társadalmi) fenntarthatóságnak is a feltétele. A fenntartható fejlődés mára meglehetösen összetetté vált fogalmát ugyancsak nehéz lenne (akár itt, akár egy könyv fejezeteként) teljes körüen bemutatni. ${ }^{4}$ llyen irányú fogalmi, illetve elméleti megközelítéssel egyébként Eickstedt - noha ezt az ő könyvétöl várnánk inkább - jellemző módon nem is foglalkozik, ellenben Käb - a multifunkcionalitás és a fenntarthatóság követelményeinek az összehasonlítása érdekében - önálló szerkezeti egységet szentel e kérdéskörnek. A fenntartható fejlődés környezeti szempontból a természeti eröforrásokkal való takarékoskodás, távlatos gazdálkodás követelményét jelenti, a jövő nemzedékek lehetőségeire is tekintettel. Fenntartható fejlődésröl csak akkor beszélhetünk (ez szükséges, de nem elégséges feltétel), ha a környezeti szempontok, érdekek beépülnek mindazon magatartások normarendszerébe, amelyek során természeti erőforrásokkal gazdálkodunk. A mezőgazdasági tevékenység - akár a hagyományos értelemben vett agrártermelésre, akár a tágabb értelemben vett ( $\mathrm{pl}$. a falusi turizmust vagy a hagyományőrző kézmüves tevékenységeket is magában foglaló, vidéki) tevékenységekre gondolunk - magától értetődően ebbe a körbe tartozik. A gazdálkodótól nemcsak (jó minőségủ, biztonságos) terméket várunk, hanem azt is elvárjuk, hogy a jó gazda gondosságával óvja a rábízott termőföldet, vizet, tájat, biológiai tartalékokat. A környezeti szempontok beépülése a KAP szabályrendszerében viszonylag előrehaladott, de persze még korántsem lezárt folyamat, mint ahogy a fenntartható fejlődés is inkább célkitűzés, mint megfelelően érvényesülő alapelv.

Azt, hogy a tevékenység diverzifikálása, a vidék sorsának alakulása, illetve a környezeti szempontoknak az agrárpolitika követelményrendszerébe való beépítése még sok feladat elé állítja a döntéshozókat, az Európai Unió is jól tudja. Nem véletlen, hogy jelenleg ez a két kérdés - a klímaváltozásra való felkészülés, a világpiaci versenyképesség javítása és a bürokrácia csökkentése mellett - a KAP soron követke-

4 A fogalom több szinten történő értelmezésére lásd BánYAI Orsolya: Kiút a zsákutcából, azaz a (fenntartható) fejlődés - jogi nézőpontból, Jogelméleti Szemle, 2011/3 (http://jesz.ajk.elte.hu/banyai47.html). 
ző, 2014-töl megvalósítandó reformjának a középpontjában áll. 2010-ben, a két monográfia kiadásának évében jelentette meg az Európai Bizottság azt a közleményét, amelyik a reform fő irányait, céljait kitűzi ${ }^{5}$ Szerzőink tehát igencsak időszerü témával foglalkoznak. A következökben külön-külön ismertetem a két munkát, majd kísérletet teszek az olvasásuk során levonható, közös tanulságok összefoglalására.

\section{A multifunkcionális mezőgazdaság agrárjogi problémái}

Käb kiindulópontja egy összetett problémakör, amelyben nemzeti, illetve uniós és nemzetközi jog feszül egymásnak, s ahol a mezőgazdaság fogalmának a szabályozási szintenként és jogterületenként egyaránt eltérő értelmezése vet fel korántsem akadémikus természetű, hanem nagyon is komoly, gyakorlati jelentőséggel bíró kérdéseket. A német agrárjog három kulcsterületén elemzett, legfontosabb jogi problémák a következők: a) Németországban a mező- és erdőgazdasági földek tulajdonának megszerzése hatósági engedélyhez kötött, $\mathrm{s}$ az engedély bizonyos hasznosítási célok esetében megtagadható. A kérdés az, hogy a hagyományostól eltérő, de a multifunkcionális mezőgazdaság fogalmába beletartozó tevékenységek folytatásához engedélyezhetö-e a földszerzés. b) A mezőgazdasági haszonbérlet kapcsán a bérlő jogosítványainak a terjedelme a kérdéses: végezhet-e a bérelt gazdaságban, illetve földön másfajta tevékenységet, mint a szüken vett mezőgazdasági tevékenységet? c) Mind a földforgalom, mind a haszonbérlet esetében jelentős változást hozott a német föderalizmusreform 2006-ban (tulajdonképpen a német szövetségi alaptörvény módosításáról van szó), amely a szövetségi és a tartományi jogalkotás, illetve végrehajtás viszonyát átrendezte. Addig az ingatlanjog területén konkuráló hatásköröket állapított meg az alaptörvény, azóta viszont a földforgalom és haszonbérlet szövetségi szintű szabályait teljes mértékben saját előírásokkal cserélhetik fel a tartományok. Ezért különösen időszerű annak a vizsgálata, hogy vajon tartalmilag fenntarthatók-e a korábbi elöírások, vagy új szabályozásra van-e szükség. d) A harmadik részterület az építésügyi jog, amely a mezőgazdaság számára különböző előnyöket biztosít a külterületi építkezések igazgatása körében. Vajon megvan-e ez a kedvező helyzete a multifunkcionális mezőgazdaságnak is? Ha nem, másfajta kedvezmények biztosíthatók-e a javára? A korábban létesített mezőgazdasági épületek használhatók-e, átalakíthatók-e az eredeti rendeltetésüktől eltérő, de a multifunkcionális mezőgazdaság fogalmába tartozó célokra?

Käb saját megfogalmazása szerint a multifunkcionalitást állítja középpontba, s az agrárjog egyes intézményeinek a bemutatását a mérceállítás kedvéért, az ahhoz szükséges mértékig végzi el. A könyv szerkezetét áttekintve azonban inkább az állapítható meg, hogy a bemutatás sorrendisége megfelel ugyan ennek a szerzői koncepciónak, de az arányok már nem feltétlenül. A magam részéről úgy vélem, hogy a

${ }^{5} \operatorname{COM}(2010) 672$. Időközben megjelentek a jogszabálytervezetek is, valamint megindult a széles körü vita is azokról. A folyamat rövid áttekintéséhez lásd a következő internetes oldalakat: http://ec.europa. eu/agriculture/cap-post-2013/communication/com2010-672_hu.pdf; http://ec.europa.eu/agriculture/cappost-2013/legal-proposals/index_en.htm; http://www.europarl.europa.eu/pdfs/news/public/focus/20110526 FCS20313/20110526FCS20313_hu.pdf. 
szerző a súlypontot inkább az agrárjog, nevesül a német (nemzeti) agrárjogon belül a mezőgazdasági üzemi jog legfontosabb jogintézményeire helyezte, s ehhez használta az értékelés során mérceként a multifunkcionalitást. Más szavakkal: kiváló alkalmat talált a nemzeti agrárjognak egy sajátos nézőpontból történő értékelésére, amelynek alapján viszonylag átfogó s föleg időszerủ képet festett e szakterületről, ami (az utóbbi évek változásaira is tekintettel) számunkra hiánypótlóvá teszi művét.

Agrárjoggal foglalkozni köztudottan nem lehet közgazdasági, politikai és szociológiai összefüggések, valamint statisztikai adatok nélkül, vagyis interdiszciplináris megközelítésre van szükség, de a jogtudományi módszerek közül is számos kínálkozik. Käb él is ezekkel; sajátos agrárjoga sokféle kutatási módszer együttes alkalmazásának az eredménye.

Így a történeti megközelítés teszi lehetővé számára, pl. a KAP és a nemzeti agrárjogok által követett első mezőgazdasági üzemi modellnek, a családi gazdaságnak és a multifunkcionális mezőgazdaság későbbi modelljének az egybevetését, a KAP immár több évtizedes ívű reformfolyamatának tükrében. Ehhez a megközelítéshez kapcsolja szerzőnk a nemzetközi hatások (OECD, GATT/WTO) elemzését is, amely hatások közismerten jelentősek a KAP újabb fejlődési irányaira nézve.

A dogmatikai módszer segítségével mutatja be a fenntarthatóság, a versenyképesség és a multifunkcionalitás célkitűzéseit; tisztázza, hogy mi a gazdaság (mezögazdasági üzem), a kiegészítő üzem vagy a hobbikert; s hogy egyáltalán mi is a mezőgazdaság jogi értelemben. Utóbbihoz a legfontosabb legális definíciókon túl (egyébként a mintegy 40 ágazati definíció mellett a BGB is ad egyet) segítségül hívja a német agrárjogi szakirodalomban oly népszerü, s már a hazai oktatásban is több helyen használt hagymaelméletet, amely a szabályozási tárgy bővülését, illetve az egymásra rakódó tevékenységköröket kiválóan szemlélteti. ${ }^{6}$ Minden esetben külön gondot fordít a jogintézményekhez kapcsolódó tényállások beható elemzésére, a szóba jövő konstellációkat és az érintett jogalanyok szempontjait egyaránt a német alapossággal gondolja végig, vagyis dogmatikai szempontból meglehetősen stabil alapokon nyugszik Käb munkája.

A különböző agrárpolitikai/szabályozási koncepciók ütközését a joggyakorlat bevonásával, mégpedig a releváns nemzeti bírósági ítéletek alapján vizsgálja. A bírói gyakorlat következetlenségeit objektív bírálattal illeti, rámutatva, hogy a változó agrárpolitika, illetve struktúrapolitika kihívásainak a felsőbíróságok rugalmasabb jogértelmezési hajlandósága inkább megfelel, mint a hatóságoké (pl. az engedélyezés körében) vagy az alsóbíróságoké.

A Passaui Egyetem disszertánsaként a tartományi jogot - amennyiben arra egyáltalán szükség mutatkozik - a bajor példákon szemlélteti. E körben is tud (legalábbis nekünk, magyaroknak) újat mondani, hiszen nálunk kevéssé ismert pl. az a körülmény, hogy az EK 1975. évi struktúrapolitikai intézkedéseinek (,hegyiparaszt-irányelv”)

${ }^{6}$ Ezt a megközelítést Grimm, Christian alkalmazta elöször (legalábbis a szakirodalomban): Von der Landwirtschaft zur Wirtschaft auf dem Lande? Gedanken zum Begriff der Landwirtschaft, Agrarrecht, 2001/1, 3.; Hazai megjelenésére lásd Fodor László: Agrárjog (fejezetek a mezőgazdasági életviszonyok sajátos szabályozása köréből), Debrecen, Kossuth Egyetemi Kiadó, 2005, 28-30.; SzILÁGYI János Ede: Az agrárjog dogmatikai alapvetései. In: Csák Csilla (szerk.): Agrárjog - A magyar agrárjog fejlödése az EU keretei között. Miskolc, Novotni Kiadó, 2010, 17-43. 
a közvetlen előzményei éppen a bajor mezőgazdaság-támogatási törvényben (1970) fedezhetők fel. Ezek az első jogszabályok, amelyek a mezőgazdaságnak a termelésen kívüli funkcióiról említést tettek, s a vidékről való elvándorlás veszélyére reflektálva kiterjesztették a családi üzem fogalmát a mellék-, illetve kiegészítő üzemekre is (a föhivatásúak mellett).

A komparatív módszert is alkalmazza müvében, bár szűk körben, s inkább csak összehasonlító adatok, mint valódi jog-összehasonlítás formájában. Ezt egyébként a német újraegyesítés és az EU keleti bővítése kapcsán teszi, pl. annak szemléltetésére, hogy a KAP a továbbiakban immár nem támaszkodhat kizárólagos jelleggel egyetlen üzemi modellre (a családi gazdaság modelljére), hiszen annak kereteit a kelet-európai mezőgazdaság túlfeszítené. A jog-összehasonlítás mellőzése mellett a kritikus olvasó szemébe ötlő, másik hiányossága a könyvnek, hogy - az uniós, illetve nemzetközi összefüggések érintése ellenére - kizárólag a német szakirodalomra, joganyagra, illetve agrárpolitikai dokumentumokra támaszkodik.

Käb munkája ennek ellenére alkalmas arra, hogy a mai magyar agrárszabályozás értékeléséhez, továbbfejlesztéséhez szempontokat találjunk benne. Ez annál is inkább hasznos lehet, mert Magyarországnak (a mező- és erdőgazdasági földek tulajdonának a megszerzésére vonatkozó szabályozás körében kapott derogáció 2014-es lejáratára tekintettel) a közeljövőben ki kell építenie azon jogintézmények rendszerét, amelyek nélkül Nyugat-Európában nem is beszélnek agrárjogról: vagyis a mezőgazdasági üzemszabályozást, ideértve az üzemi struktúra és az üzemforgalom, illetve földforgalom elöírásait. Jellemző, hogy a hazai pártok és a sajtó szeretik mindezt földkérdéssé degradálni, holott ennek a megközelítésnek a végzetes következményeit (az agrárstruktúra felszabdalását) Magyarország már nemegyszer megszenvedte, legutóbb a rendszerváltás során. Az üzemben való gondolkodás, a közgazdasági tartalomnak is megfelelő komplex megközelítés nem maradhat el, s erre a német jog jó példa. Käb bemutatja a földforgalom engedélyezési rendszerét; az elővásárlási jogokat; a haszonbérletnek az üzemre (egész gazdaságra) és a földre vonatkozó, s egymástól eltérő szabályait; a külterületi földrészletek beépítésének („más célú hasznosításának") a feltételeit és a területrendezési jog adta kereteket. A német megoldások természetesen nem mind vehetők át, de az engedélyezési rendszer bevezetése vagy az üzemi és a földbérlet szabályozásának a kettéválasztása (ami a tevékenység célját és közgazdasági tartalmát jobban figyelembe vevő szabályozás) valószínüleg hasznos lenne.

Az említett tárgykörök közül számunkra most kétségkívül a földforgalom szabályozása a legérdekesebb. Ennek központi eleme az engedély, amely - mint a szövetségi alkotmánybíróság maga rögzíti - nem a földforgalom szabályozását jelenti, hanem az agrárstruktúrát, vagyis a mezőgazdasági üzemi rendszert fenyegető veszélyek elhárításának az eszköze. A törvény szempontjából a mezőgazdasági tevékenység a termeléssel valósul meg, s általában kockázati tényezőként értékelik, ha a földet olyan személy szerezné meg, aki nem főfoglalkozású, hanem mellékfoglalkozású gazdálkodó. A főfoglalkozásúak előnyben részesítésének alkotmányosan elfogadott indoka, hogy az ilyen korlátozás az agrárstruktúra javítását szolgálja. A föfoglalkozású gazdálkodók elsőbbségének az elve azonban nem egy merev szabály, azt a szövetségi felsőbíróságok már elég rugalmasan értelmezik. Käb - erre a 
gyakorlatra is figyelemmel - kidolgozott egy három kérdésből álló tesztet, amelynek segítségével az engedélyező hatóságok - jogszerüen - eltérhetnek az elvtől:

1. Van-e konkurens jelentkező a földterületre?

2. A kérelemben foglaltak engedélyezése negatív hatással járna-e az agrárstruktúrára? Azaz:

a) Ellentétes-e a tulajdonszerzés az agrárstruktúra javításáról szóló programmal, intézkedésekkel? Ha nincs ilyen ellentét, van-e egyéb, felismerhető hátrány?

b) Van-e megfelelő szakértelme a tulajdonszerzést kérelmezőnek a tervezett tevékenység folytatásához?

Az eddig említett szempontok együttesen vizsgálandók, így pl. a szakértelem hiányát adott esetben kompenzálhatja, ha a tulajdont megszerezni kívánó személy korábban jelentős beruházásokat eszközölt az adott területen, illetve üzemben. (Úgy vélem, erre a magyar jogalkotónak is gondolnia kell a mező- és erdőgazdasági földek forgalmának korlátozásakor.)

3. A tervezett tevékenység vizsgálata a konkurens oldalán: az a struktúra javítását szolgálja-e? Ha igen, akkor az az engedélyezés ellen (és a konkurens jelentkező előnyben részesítése mellett) szól. Természetesen a konkurens esetében is vizsgálni kell, hogy az ő szerzésével nem romlana-e az üzemszerkezet, illetve hogy neki van-e megfelelő szakértelme. Ezek mellett egyetlen - polgári jogi természetű - kérdés van hátra: hogy megadja-e a kialkudott vételárat.

Az engedély megtagadására a szerző szerint csak akkor kerülhet sor, ha mindhárom kérdésben azt támasztják alá a válaszok. Egy ilyen jogértelmezés a feltétele annak, hogy a földforgalmi törvény előírásai ne álljanak a multifunkcionális mezőgazdasági modell megvalósításának az útjában. Jogtechnikai szempontból ezt a jogalkotó azzal teszi lehetővé, hogy határozatlan jogfogalmakat használ (mint amilyen az agrárstruktúra javítására irányuló intézkedés), illetve hogy az agrárpolitikai, struktúrapolitikai célokat nem foglalta bele a földforgalmi törvénybe. Így egyúttal az az előnye is megvan a szabályozásnak, hogy az agrár-, illetve struktúrapolitika változása nem indokolja a törvény módosítását. Végső soron ma már, ahogyan a struktúra fogalma is kitágult (ti. nemcsak az üzemméret, az üzemi területek elhelyezkedése tartozik a fogalom jelentéstartományába, hanem pl. a környezetállapot, a munkaerő eloszlása és lakhelye stb. is), a multifunkcionális mezőgazdaság tevékenységei beleérthetők a struktúra javítására irányuló intézkedések körébe, s így nincs akadálya az engedélyezésnek, vagyis az uniós elképzeléseknek megfelelő szerkezetváltásnak.

Az már egy másik kérdés - értékel a szerző -, hogy a törvény eme rugalmasságának olyan következménye is van, hogy több évtizedes fennállása alatt nem sikerült érdemben javítani a rendkívül kedvezőtlen adottságú, elaprózott német gazdaságszerkezeten. További konzekvencia, hogy a tartományoknak nem szükséges saját törvényt alkotniuk a földforgalom szabályozására.

A jelenlegi szabályozási elképzelések tükrében egyébként az látható, hogy a Käb által értelmezett német szabályozás kevésbé korlátozó, mint a tervezett magyar szabályozás. ${ }^{7}$ A magyar törvénytervezet ugyanis (legalább részben) a struktúrapolitikai

7 Lásd a T/7979. sz. törvényjavaslat I. és II. fejezetét (2012. július). 
célokat is magában foglalja (pl. amikor a földszerzést csak a földműves számára teszi lehetővé, s megmondja, milyen feltételekkel válik valaki földmüvessé). Németországban ettől eltérően az engedélyező hatóság feladata a negatív strukturális hatás megállapítása, s ezt a bíróság előtt vitatni is lehet. Nem feltételezik eleve minden, nem mezőgazdasággal foglalkozó személyről, hogy földspekuláns.

\section{Hogyan lesz a termelöböl a vidék gondnoka?}

Eickstedt munkájának az előszava szerint kifejezetten a KAP reformjáról kibontakozó vitához kíván hozzájárulni, így az ő vizsgálatának fókusza első sorban az uniós jog (különösen az 1698/2005. és a 73/2009. sz. EK-rendeletek) előírásaira, illetve annak jövőbeli alakulására irányul. Azt a kérdést igyekszik megválaszolni, hogy vajon hogyan tudja a KAP a környezeti érdekeket érvényesíteni anélkül, hogy az agrárpolitikai szempontok elkallódnának a szabályozás dzsungelében. Megközelítése nem agrárjogi, hanem határozottan környezetjogi; lévén kiindulópontja jogi szempontból a környezetvédelmi szabályozás módszertana. Az a tágabb elméleti közeg is, amelyben elemzéseit végzi, szintén a környezetvédelemé, ilyen pl. a környezet-gazdaságtan, amelynek eredményei erőteljesen jelen vannak a könyvben.

Az első fejezetek - az agrárkörnyezeti tárgyú közlemények túlnyomó részével azonos módon - a mezőgazdaság és a környezetvédelem ambivalens viszonyával foglalkoznak, rögzítve az integráció (a környezeti szempontoknak az agrárpolitikába való beépítése) igényét, s hogy ehhez a jogalkotó számára az eszközök gazdag tárháza kínálkozik. A szerző a történeti módszer alkalmazásával áttekinti a KAP alakulását, egészen onnantól kezdve, amikor annak még semmilyen környezeti célja nem volt, a KAP immár bő két évtizede zajló „ökologizálásáig”. Ennek során szükségszerüen támaszkodik a természettudományok eredményeire is.

Eickstedt ezt követően a teljesség igényével veszi sorra az érintett előírásokat, s jogintézményi elemzést végez, mégpedig - könyvének szerkezetét is meghatározó módon - kettős megközelítésben. Ugyanazon előírásokat előbb a környezetvédelem, majd pedig az agrárpolitika eszközeiként vizsgálja. Természetesen követi a KAP belső rendszerét is, annak megfelelően előbb az első pillérről, azután a második pillérröl szól. A területpihentetés, a kölcsönös megfeleltetés (azon belül is a növényvédelem, vízvédelem, a szennyvíziszapok felhasználása, a helyes gazdálkodási gyakorlat és a jó környezeti állapot követelményeinek számonkérése), a moduláció stb. nálunk is jól ismert szabályai annyiban kerülnek itt sajátos megvilágításba, hogy a szerző a kölcsönös megfeleltetéshez tartozó nemzeti szabályokról is ír, külön vizsgálva, hogy azok mennyiben térnek el az uniós sztenderdektől. A másik sajátosság, hogy egyetlen ágazatot, mégpedig a szántóföldi növénytermesztést választotta ki szemléltetésül, s az abban felmerülő problémákra koncentrált. Eme ágazatra vélhetően azért esett a választása (ezt ő maga egyébként nem indokolja), mert a KAP első pillérén belül mindig is modellértékű volt a többi termékcsoport szabályozása során. Mivel pedig a magyar mezőgazdaságban éppen a szántóföldi növénytermesztés a meghatározó (mondhatni túlsúlyos) ágazat, a könyvben megfogalmazott értelmezések, vélemények számunkra is relevánsak. 
A szerző nem elégszik meg a de lege lata elemzésekkel, hanem javaslatokat is megfogalmaz arra nézve, hogy az agrár-környezetvédelmi eszköztár miként lenne bővíthető. Käbbel ellentétben ő nem készített külön értékelő, illetve összegző részt az egyes alfejezetekhez; ugyanakkor a monográfiát lezáró, összegző fejezet viszonylag nagy terjedelmü, bő 20 oldalas.

Eredményei közül azok a legérdekesebbek, amelyek a könyv leghosszabb, közel százoldalas, 4. részében jelennek meg. A szántóföldi növénytermesztés szempontjából az uniós szabályok közül a területpihentetés, az egységes támogatás, az üzemi tanácsadási rendszer és a kölcsönös megfeleltetés intézményeit tekinti meghatározónak, ezért azokról értekezik bővebben, mégpedig többnyire a leíró, illetve elemző módszer alkalmazásával. Ezen módszerek alkalmazása mellett összehasonlítja egymással az uniós és a német követelményeket, az eltérések kimutatása érdekében. Eickstedt ezeket az eltéréseket nemcsak számba veszi - megállapítva, hogy Németország túllépte az uniós követelményszintet, pl. a növényvédő szerek használatához szükséges szakismeret, a növényvédelmi eszközök minősítése vagy az ún. nitrátmérleg előírásával - hanem két szempontból értékeli is. Az első szempont kissé eltér választott témájától, amennyiben az uniós és a tagállami környezeti követelmények viszonyáról az általánosságok szintjén ír (hogyan enged eltérést a szerződési jog a tagállamok számára?). A másik szempont azonban már kifejezetten az agrár-környezetvédelmi jog világába s sajátos eredményekre vezet.

Ezen belül először is összeveti az uniós agrárkörnyezeti normákat abból a szempontból, hogy azok (pl. a határozatlan jogfogalmak révén) milyen mozgásteret engednek a tagállamoknak a konkrét követelmények megállapítására. - Minél nagyobbat, annál nagyobb egyúttal a versenytorzulás kockázata is. A szerző azokat a megoldásokat üdvözli, amelyek konkrétabbak, egyértelmübbek, illetve a tagállamok területén belül nem tesznek lehetővé differenciálást (ilyen pl. a szennyvíziszapokról vagy a mütrágyákról szóló jogszabály, szemben a nitrátirányelvvel vagy a növényvédő szerek szabályozásával). Az ilyen megoldások alkalmazása mellett ugyanis egyértelmübben megítélhető, hogy a tagállami norma belül maradt-e, avagy túlterjeszkedett az irányelv transzpozíciójára irányuló kötelezettségen. Ez pedig nem tisztán elméleti, hanem bizony praktikus kérdés is, hiszen - mint a szerző rámutat - utóbbi esetben a kölcsönös megfeleltetés nem terjedhet ki a tagállami előírásra. Azaz ilyen előírás be nem tartása a kifizetések körében nem szankcionálható. (Figyelemre méltó egyébként az ezzel ellentétes, német közigazgatási gyakorlat.)

A versenytorzulások szempontjából, s egyúttal az agrárkifizetések orientáló szerepét illetően is a leginkább problematikusnak a kölcsönös megfeleltetést tartja Eickstedt, figyelemmel arra, hogy itt a tagállami mozgástér nem csupán nagy, de ráadásul nem jogszabályokban rögzített követelményekre vonatkozik. Álláspontja szerint ez a KAP két alrendszere közötti határok elmosódásával is együtt jár. A következő elemzések a kifizetések csökkentéséről és megvonásáról szólnak, a gazdálkodók (a közvetlen kötelezettek) felelőssége mellett a harmadik személyek magatartásának következményeit is bemutatja a szerző. Álláspontja szerint nincs biztosítva, hogy a felelősség és a csökkentés mértéke mindig arányban legyen egymással.

A KAP második pillérében (a programok önkéntességéből, illetve a pluszkövetelményeknek való megfelelés követelményéből fakadóan) egészen más a környezet- 
védelmi szempontok szerepe, ugyanakkor az idetartozó szankciórendszer nagyban hasonlít az első pilléréhez. A fejezet erről szóló elemzései némileg egysíkúra sikerültek, mivel alig lépnek túl a leíráson.

A magam részéről vitathatónak tartom, hogy a szerző az agrárkifizetésekből való kizárást a büntetőjog alapelveinek a tükrében értékeli. Igaz ugyan, hogy egyes tagállamok az ilyen szankciókat büntetésként értelmezik, de büntetőjogi besorolásukat az Európai Bíróság (védve ezzel az EU hatáskörét) rendre elveti.

A hatályos jogról alkotott véleményét a szerző úgy összegzi, hogy az agrár-környezetvédelmi szabályozás eszközei nem csupán sokfélék, de több funkciót is betöltenek egyszerre, azaz „multifunkcionálisak”. Ezért ezek az eszközök önmagukban is úgy orientálják a gazdálkodót, hogy a táj gondozójává váljon. A szabályozás ugyanakkor nem kellően hatékony. (Mindegyik állításával egyet kell érteni.)

A hatodik rész ezzel a problémával foglalkozik, rámutatva először is egy sor jogalkotói tévedésre, alaptalan várakozásra. Ilyen szerinte, hogy a kölcsönös megfeleltetés követelményei és szankciórendszere javítani fogja a környezetvédelmi szabályozás hatékonyságát, valamint a közvetlen kifizetések társadalmi elfogadottságát.

A KAP jövőbeli reformja kapcsán konkrét javaslatokat fogalmaz meg, amelyek közül némelyik első olvasásra meglepő. A szerző mindenesetre - föként közgazdasági összefüggésekkel - kellően alátámasztja azokat. A kötelező területpihentetés és a támogatási jog elidegenítésére vonatkozó szabályokat összhangba kell hozni, nehogy a kedvezőtlen adottságú területekre koncentrálódjon a területpihentetés, ahol már amúgy is extenzív művelés a jellemző (megjegyzem: az ún. „kicsúszás” jelenségét a szakirodalom már a korábbi szabályozás kapcsán is leírta, ez a javaslat tehát ésszerünek tủnik). A moduláció mértékét (vagyis az első pilléres támogatások arányos csökkentését, s a ki nem fizetett összegböl második pilléres intézkedések finanszírozását) növelné. (Ezt a szemléletet követi egyébként az Európai Bizottság is, akinek a tervei szerint a moduláció jelenlegi 10\%-os mértéke 30-ra emelkedne.) Sőt: szerzőnk az egész finanszírozási rendszert felülvizsgálná, minden, a gazdák bevételét növelő támogatást az első pillérbe helyezve, s a másodikban csak a mezőgazdaságtól független (strukturális) kifizetéseket hagyva meg.

Álláspontja szerint javítaná az agrár-környezetvédelem hatékonyságát, ha a kölcsönös megfeleltetés, illetve a növényvédő szerek és trágyák követelményeinek a betartását kivennék a támogatási szempontok közül. Más szóval: e kötelezettségek betartását ne honorálja pénzügyileg az unió, és egyébként is csak olyan követelményeket vegyenek figyelembe, amelyek betartása jól ellenőrizhető. Bizonyos esetekben pedig ne legyen elegendő valamilyen magatartás, intézkedés megtétele, hanem annak az eredményét kérjék számon ( $p l$. ha egy terület vagy faj egyedeinek a megörzése a követelmény). Érveit elolvasva tulajdonképpen védhető álláspontról van szó.

A szerző ebben a fejezetben számba veszi a környezetvédelmi szabályozás néhány olyan eszközét, amelyeknek a mezőgazdaságban való alkalmazására eddig egyáltalán nem, vagy csekély mértékben került sor. llyenek a különféle adók és a forgalmazható kvóták (pl. trágyázásra, növényvédő szerekre), az együttmüködési típusú (környezetvédelmi megállapodások) vagy az üzemgazdasági eszközök (mint amilyen az EMAS). Ezek felsorakoztatása némileg elavult megoldás, hiszen a környezetjogi szakirodalom évtizedekkel ezelőtt foglalkozott velük a szabályozás új módszereiként. 
Mindenesetre a szerző következtetései nem annyira a jövőbeli alkalmazásuk mellett, mint inkább az ellen szól, figyelemmel a mezőgazdaság sajátosságaira (elsősorban közgazdasági összefüggésekre).

A könyv összességében korrekten teljesíti célkitűzéseit. Igaz, a téma aktualitásához mérten a megközelítés esetenként lehetne korszerübb is. Örömmel vettem volna továbbá, ha - pl. a bírói gyakorlat segítségével - azt is bemutatja, hogy maguk a (német) gazdálkodók hogyan élik meg a környezeti szempontok térhódítását, erösödését a KAP követelményrendszerében.

\section{4. Értékelés és kitekintés magyar szemmel}

A német és a magyar agrárjog ugyan közismerten különbözik egymástól, s ezért nem ugyanazok a problémák merülnek fel a gyakorlatban, mégis nagy haszonnal forgathatjuk a német szakirodalmat. Käb és Eickstedt könyve erre külön-külön, de együtt, egymást jól kiegészítve is kellő bizonyságul szolgál. Nemcsak azt mutatják meg, hogy milyen a szabályozás, hanem azt is, hogy mi van annak felszíne alatt.

A multifunkcionális mezőgazdaság problémáinak áttekintése azzal a tanulsággal jár, hogy a multifunkcionalitás tulajdonképpen nem új jelenség, legfeljebb csak új szó. A mezőgazdaság pozitív externáliáit takarja, amelyek a 20. század közepéig magától értetődőek voltak, s csak miután háttérbe szorultak (a KAP, illetve a müvelési módszerek megváltozása miatt), azt követően kezdtek róla beszélni. Ma, a KAP újabb reformja előtt nagy jelentőséggel bír az a kérdés, hogy vajon a politika, illetve a jogi szabályozás mely pozitív externáliákat ismeri el, hiszen ettől függ a támogatás, vagy épp a földszerzés.

Az agrártámogatások kifizetésének, másképp fogalmazva az erős KAP fenntartásának az egyik indoka éppen e pozitív externáliák megőrzése, akár termelés (azaz a hagyományos, szűk értelemben vett mezőgazdasági tevékenység) hiányában is. A másik igazoló körülményt az jelentheti, ha a mezőgazdasággal szemben magasabb elvárásokat támasztanak, $\mathrm{s}$ a támogatással ezeket ellentételezik. Az ilyen elvárások jelentős részben az agrár-környezetvédelem körébe tartoznak. Végeredményben mindkét szerző úgy foglal állást, hogy a költséges és nemzetközi szinten is vitatott uniós agrártámogatási rendszert inkább a környezetvédelem, mintsem az agrárstruktúra javítása (illetve a multifunkcionalitás) igazolhatja.

Végül, egy a sorok közül kiolvasható tanulság: a tagállami jogalkotónak nem feltétlenül elegendő figyelemmel lennie az európai uniós jogra, amely szerint a tulajdonszerzési, haszonbérleti (esetleg öröklési) stb. korlátozások csak bizonyos feltételekkel, így pl. csak a KAP által deklarált közérdekủ célok érdekében vezethetők be. ${ }^{8}$ A belső piacnak való megfelelés ellenére ugyanis még fennáll a veszélye annak, hogy a földforgalmat esetleg túlzott mértékben korlátozó szabályozás a multifunkcionális mezőgazdaság célkitüzésével ellentétes irányban hat.

8 Az elfogadható indokok összefoglalására lásd SzILÁGYı János Ede: Az Európai Unió termőföld-szabályozása az Európai Bíróság joggyakorlatának tükrében. In: Csák Csilla (szerk.): Az európai földjogi szabályozás aktuális kihívásai. Miskolc, Novotni Alapítvány, 2010, 269-281. 